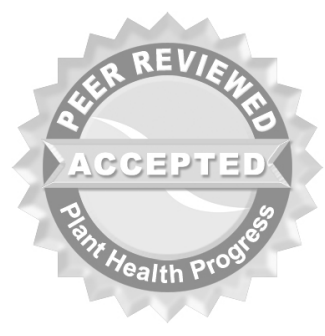

(c) 2005 Plant Management Network.

Accepted for publication 14 February 2005. Published 21 February 2005.

\title{
Abnormal Leaf Development on White Oaks Linked to Drift of Chloroacetamide Herbicides
}

\author{
J ayesh B. Samtani, Graduate Research Assistant, John B. \\ Masiunas, Associate Professor, and James E. Appleby, Associate \\ Professor, University of Illinois, Department of Natural Resources and \\ Environmental Sciences, 1201 W. Gregory Drive, Urbana 61801
}

Corresponding author: Jayesh B. Samtani. jsamtani@uiuc.edu

Samtani, J. B., Masiunas, J. B., and Appleby, J. E. 2005. Abnormal leaf development on white oaks linked to drift of chloroacetamide herbicides. Online. Plant Health Progress doi: 10.1094/PHP-2005-0221-01-HN.

During the last few decades, white oak (Quercus alba L.) in the north central region have developed malformed spring leaves often called "leaf tatters". The symptoms begin with the death of some interveinal leaf tissues, eventually leaving only the main leaf veins with little interveinal tissues present (Fig. 1). Leaf tatters reduces the overall canopy of trees, making them more susceptible to other stresses. Leaf tatters has been reported in Illinois, Indiana, Iowa, Michigan, Minnesota, Missouri, Ohio, and Wisconsin. In the landscape, tatters has been observed only on white oak and related white oak species. Red oak (Quercus rubra L.) does not seem to be affected by tatters (J . E. Appleby, personal observations). Winter injury, frost, insect attack, and herbicide drift were all thought to be possible causes of leaf tatters. We hypothesized that leaf tatters on white oak was due to herbicide drift from herbicide applications onto corn and soybean fields.

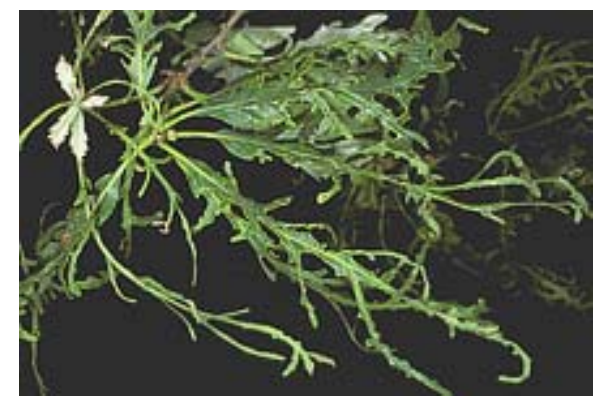

Fig. 1. White oak leaves showing severe symptoms of leaf tatters (Photo by J. E. Appleby).

In an experiment conducted in 2004 at Champaign, IL, two-year-old potted white oak seedlings $0.6 \mathrm{~m}$ in height were treated with six herbicide treatments at three concentrations of $1 / 4,1 / 10$, and $1 / 100 \times$ the standard field-use rate. These herbicides and their standard field-use rate of a.i. included a phenoxy herbicide- 2, 4-D ester (LV 400) at $1.5 \mathrm{~kg} / \mathrm{ha}$; glyphosate (Roundup Weathermax) at 1.1 $\mathrm{kg} / \mathrm{ha}$; 2, 4-D ester + glyphosate at $0.8 \mathrm{~kg} / \mathrm{ha}+1 \mathrm{~kg} / \mathrm{ha}$, respectively; a benzoic herbicide -- dicamba (Clarity) at $0.7 \mathrm{~kg} / \mathrm{ha}$; a chloroacetamide + triazine herbicide -- acetochlor + atrazine (Harness Xtra) at $3.5 \mathrm{~kg} / \mathrm{ha}$; and a chloroacetamide herbicide -- metolachlor (Dual Magnum) at $2.0 \mathrm{~kg} / \mathrm{ha}$. The trees were sprayed with the herbicides at three growth stages: (i) swollen bud, (ii) leaves just unfolding, and (iii) expanded leaves (1). White oak treated with water served as controls. In addition, two-year-old potted red oak, $0.7 \mathrm{~m}$ in height, treated with water were included as controls non-susceptible to tatters. A compressed air spraying chamber with a moving 80015 EVS spray nozzle delivering 187 liter/ ha at $207 \mathrm{kPa}$ was used to apply the herbicides. Treated oaks 
were arranged in a completely randomized design with seven single-tree replications for each treatment. The experimental site was an open plot, approximately $3 \mathrm{~km}$ from the nearest crop fields.

Leaf tatters were observed on two, three, and three out of the seven white oaks treated with metolachlor at leaf unfolding stage at concentrations of $1 / 4 \times$, 1/10x, and 1/ $100 \times$ (Fig. 2), respectively. For acetochlor + atrazine, tatters were observed on four, four, and five out of the seven white oaks treated at $1 / 4 \times$, $1 / 10 \times$, and $1 / 100 \times$ concentrations, respectively, when treated at the leaf unfolding stage. Leaf tatters did not occur on white oaks treated with acetochlor + atrazine or metolachlor at the other two growth stages or on white oaks treated with other herbicides at all three growth stages. The red and white oak controls did not show tatters. After 45 days following treatments with metolachlor or acetochlor + atrazine, white oak seedlings produced a new flush of growth which was unaffected by leaf tatters (Fig. 3).

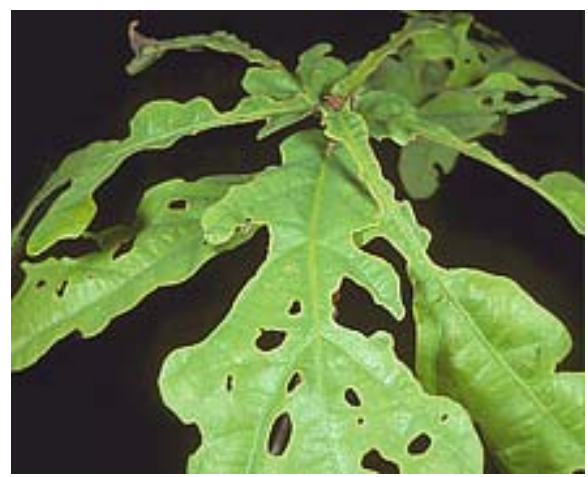

Fig. 2. Injury on white oak from metolachlor at $1 / 100 \times$ of the field use rate (Photo by J. E. Appleby).

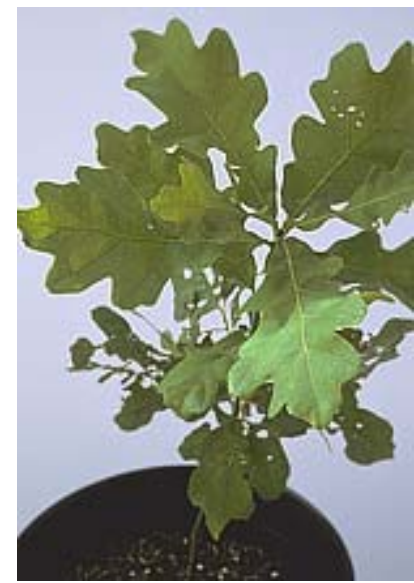

Fig. 3. Later in the growing season the oaks which previously had tatters produced a new flush of normal leaves. Note the damaged leaves below the normal leaves (Photo by J. E. Appleby).

The study indicates that drift of chloroacetamide herbicides is a possible cause of the leaf tatters syndrome. We will be repeating the experiment next year and will evaluate alternative ways of treating the seedlings to confirm growthspecific susceptibility of white oak to chloroacetamides.

Literature Cited

1. Kolb, T. E., and Teulon, D. A. J . 1991. Relationship between sugar maple budburst phenology and pear thrips damage. Can. J . For. Res. 21:1043-1048. 